Social Sciences, Humanities and Education Journal (SHE Journal)

Volume 2(2) 179 - 188, May 2021 | ISSN: 2720-9946 (Online) | ISSN: 2723-3626 (Print)

The article is published with Open Access at: http://e-journal.unipma.ac.id/index.php/SHE

\title{
THE EMERGING ROLE(S) OF LAW IN REPRODUCTIVE HEALTH CARE IN NIGERIA: A COMPARATIVE ANALYSIS
}

Patrick Chukwunonso Aloamaka $\square$; Faculty of Law, Univeristy of Calabar, Calabar, Cross River State, Nigeria.

Favour AdaezeIbekwe ; Faculty of Law, Univeristy of Calabar, Calabar, Cross River State, Nigeria.

\begin{abstract}
There is no gainsaying the fact that the ICPD Call for A ction P rogramme and the Beijing Conference has had pivotal roles in the evolution and growth of Reproductive Health Laws. These reproductive health laws in turn have served as a means of resolution to Reproductive health issues which include but are not limited to issuessuch as early and under-aged marriage, adolescent pregnancy, harmful traditional practices examples of which include Female Genital Mutilation (FGM), widowhood practice, domestic violence, abortion, HIV/AIDS, Maternal mortality/morbidities and improper family planning. Many challenges remain in the effort to addressthese health issues. The major setback has been the failure of state parties (c ountries) to incorporate these I nternational Reproductive Health C are instruments into their legal system as well as the implementation of these laws.This paper highlights the legality of the ICPD in the context of International Law and also focuses on the emerging roles of laws in Reproductive Health Care in Nigeria.
\end{abstract}

Keywords: Law, Nigeria, of Reproductive Health Laws.

faibekwe@gmail.com

Aloamaka, P. C. \& Adaezelbekwe, F. (2021). The emerging role(s) of law in reproductive health care in nigeria: A comparative analysis. Social Sciences, Humanities and Education Journal (SHE Journal), 2(2), 179 - 188. DOI: $10.25273 /$ she.v2i2.9505

\section{(cc) BY-NC-SA}

Published by Universitas PGRI Madiun. This work is licensed under the Creative Commons Attribution-NonCommercial-

ShareAlike 4.0 International License. 


\section{INTRODUCTION}

The United Nations International Conference on Population and Development (ICPD) held in Cairo, Egypt between $13-15^{\text {th }}$ September 1994, established the programme of action which has become the leading and international consensus document emphasizing the intrinsic and mutually buttressing linkages between human rights, gender issues, sexual and reproductive health and rights for women (Ghabbour 1994). The ICPD Programme of Action acknowledges that recognizing the right to reproductive health care is a critical ingredient of assuring reproductive rights (Ghabbour 1994). The outcome of the ICPD program of action is highlighted on the emancipation of women and the advancement of their reproductive health status as a highly important end in the achievement of sustainable development and legal rights (Aniekwu 2011; Udungeri and Aloamaka 2017). The ICPD Programme of Action was the first international policy document to define reproductive health as;

"a state of complete physical, mental and social well-being and not merely the absence of disease or infirmity, in all matters relating to the reproductive system and to its functions and processes. Reproductive health implies that people are able to have a satisfying and safe sex life and that they have the capacity to reproduce and the freedom to decide if, when and how often to do so. Implicit in this last condition are the right of men and women to be informed and to have access to safe, effective, affordable and acceptable methods of family planning of their choice, as well as other methods of their choice for regulation of fertility which are not against the law, and the right of access to appropriate health care services that will enable women to go safely through pregnancy and childbirth and provide couples with the best chance of having a healthy infant" (Defeis 2010, p. 396).

Some issues relating to reproductive health are sexual violence, domestic violence, maternal health care, harmful traditional practices, improper and/or lack of and wrong family planning and abortion, etc. Reproductive health issue whilst not gender restrictive, women have more consistently been at the bane of and borne the brunt of reproductive issues being the more vulnerable gender and requiring protection of the law particularly from an international perspective. Little wonder there has been an argument in certain quarters that women qualify for International protection as minorities drawing from how the gender has become endangered particularly in certain societies (Ibekwe et al., 2020).

\section{IS THE ICPD INTERNATIONAL LAW?}

To answer the question whether the ICPD is international law which is in itself a jurisprudential contention, onemust first analyse the meaning and concept of international law. According to Prof. Beth Simmons, International law can be defined as "a body ofprinciples, customs, and rules recognized aseffectively binding obligations by sovereignstates in their mutual relations" (Glahn \& Taulbee 2015, p. 23). In line from the above definition term international law can refer to three distinct legal disciplines namely:

1) Public International Law which governs the relationship between states and international entities. It includes these legal fields; treaty law, law of sea, international criminal law, the laws of international humanitarian law, etc. 
2) Private International Law: Addresses the question of which jurisdiction may hear a case and the law concerning which jurisdiction applies to the issues of the case.

3) Supranational Law: Concerns regional agreements where the laws of nation states may be applicable.

The two traditional branches of the fields are: 1) Jus gentium - Law of nations; 2) Jus inter gentes - Agreement between nations.

ICPD is a United Nations Programme for population policies aimed at empowering couples and individuals especially women to make decisions about the size of their families providing them with the information and resources to make such decisions and enabling them to exercise that their reproductive rights that are already recognised in domestic and international law.

From the foregoing, the ICPD can be regarded as a source of international law. Even if it is a mere policy declaration, its contents are recognised by States who participated in general. "Although ICPD is not enforceable, some countries have developed their laws by including some provisions of ICPD which makes it binding on their citizens, but that is not the case in Nigeria" Shapiro 2014, p. 378).

Like other international instruments, the ICPD has not been ratified in Nigeria due to the reservation of section 12 of the Constitution of the FRN as amended, which provides that:

"No treaty between federation and any other country shall have force of law to the extent to which any such treaty has been enacted into law by the National Assembly...." (Federal Republic of Nigeria 1999)

States that participated in the ICPD in Cairo are obliged to incorporate and implement the provisions of international instruments and conventions that protect women's reproductive health. The ICPD was a call for action for states to implement the reproductive health rights. One can argue that the ICPD is an international convention or treaty which is not binding on member states which participated. ICPD can be regarded as a source of international law and not international law itself because it is not enforceable. Further to this, much of international law is consent based governance. This means that a member state of the international community is not obliged to abide by this type of international law. Unless it has expressly consented to a particular cause of conduct. This is an issue of state sovereignty. However, other aspects of international law are not consent based but still are obligatory upon state and non-state actors such as customary international laws.

\section{CUSTOMARY INTERNATIONAL LAWS}

The international Court of Justice defines customary international law in Article 38(1)(b) as: "Evidence of a general practice accepted as law. This is generally determined through two factors: The general practice of states and what states have accepted as law" (D'Amato \& Abbassi 2006, p. 57). There are several kinds of customary laws recognised by States. Customary international laws are those aspects of international law that derive from custom. It exists were:

1) a certain legal practice is observed and

2) the relevant actors consider it to be law (opinio juris) most customary laws deals with the standards of the community that have been long-established in a given locale. However, the term can also apply to areas of international law.

Customary laws have supportive court rulings and case law, that has evolved over time to give additional weight to their rule as law and also to demonstrate the trajectory of evolution (if any) in the 
interpretation of such law by relevant courts. Along with general principles of law and treaties, customs is considered by the international court of justice, jurists, the United Nations, and its member States to be among the primary sources of international law. From the foregoing, the ICPD qualifies as customary international law because state parties observe these general practices but are not binding on them.

\section{EMERGING ROLE(S) OF LAW IN REPRODUCTIVE HEALTH CARE}

Generally, the role of law in reproductive health care is to provide for the legitimacy of a situation or conduct to offer remedies against reproductive rights violations and advance reproductive health goals (Aniekwu 2011). Even though laws can be based on customs or moral values, they also tend to be expressly enacted by politically composed legislatures (Aniekwu 2011). The purpose of reproductive health laws is to regulate state actions and matters pertaining to reproductive health care, as well as giving legal status to policies and application of human rights provision that protect women's health (Gable 2009). However, for this research, the emergence of the roles of law in reproductive health care will be examined into three main categories; International, Regional and National.

\section{International}

Tremendous progress has been made not just in the area of health care development but also in the human rights issues involving the right to non-discrimination and other human rights violations which has created a fundamental shift in the international community. The two main instruments that contributed to the development of reproductive health care in the international community are the ICPD and the Beijing meetings. These two international instruments provide an important basis on which state legislative and judicial machineries could build in order to develop reproductive health laws (Aniekwu 2011). However, countries at both judicial and legislative levels are starting to address the application of the existing legal system to the newly recognised requirements of reproductive health (Patel et al., 2016; (Ikonomwan and Aloamaka 2018; Ikonomwan and Aloamaka 2020)). There are several sources of international instruments that have been relevant in reproductive health care, and these includes;

1) The 1993 Vienna Declaration and Programme of Action

2) The Programme of action of the 1993 U.N. International Conference On Population And Development (ICPD)

3) The 1995 Beijing Declaration and Platform for Action, UN Fourth World Conference on women.

4) UN Convention on the Elimination of all forms of Discrimination against Women (CEDAW)

5) UN Convention on the Rights of the Child (CCRC)

6) UN Convention against torture and other cruel, inhuman or degrading treatment or punishment (CAT), etc.

Countries that have ratified some of these relevant international human rights conventions as they relate to reproductive health care have only done so only subject to the reservations that their local and domiciliary laws are not compromised (Nielsen \& Simmons 2015).

Article 20, Committee on Economic, Social and Cultural Rights in 2000 recommend that states should integrate a gender perspective in order to promote better health outcomes for both men and women (Heyns \& Viljoen 2002). It further recommended that the major goal for legislators should be aimed at providing for a reduction of women's health risks, domestic violence and protection from 
harmful traditional cultural practices. And states are obliged to ensure that harmful social or traditional practices do not interfere with access to pre and post-natal care and family planning (Heyns \& Viljoen 2002).

The CEDAW which is the primary international treaty also confers legal obligations on the state to protect women's access to health care (Englehart \& Miller 2014). State parties are also obliged to ensure the satisfaction of minimum essential levels of the right to reproductive health enunciated in the UN international conference on population and development's programme of Action. In the area of maternal mortality and morbidity, the ICPD programme of Action recognises that women have the "right of access to appropriate health care services that will enable [them] to go safely through pregnancy, and child bearing and provide couples with the best chance of having a health infant (Rahman 2003). The ICPD Programme of Actions targets for the reduction of maternal mortality were integrated into the Millennium Development Goals (MDGs), wherein countries agreed to reduce their 1990 maternal mortality rates by 75 percent by 2015 (Rahman 2003).

The Millennium Development Goals project has eight Goals and three of them are aimed at improving maternal health, reducing child mortality and halting the spread of HIV/AIDs. The others, goals are aimed at reducing malaria and other diseases, eradicating poverty and hunger, achieving universal primary education, promoting gender equality, empowering women and ensuring environmental sustainability. The goals are closely related to a reproductive health care laws and are based on the principles of human dignity, equality and equity ().

\section{Regional}

In different regions of the world, several countries have been successful in integrating reproductive health laws into the existing constitutions, legal systems, not as separate laws 0 . While some countries enacted their separate laws on reproductive health care, others developed laws limited to achieving a particular goal in reproductive health care.

\section{Examples of Countries in Europe:}

In the area of maternal mortality, Armenia as a country has taken targeted measures in order to reduce maternal mortality including promoting the maternal health of marginalized groups such as adolescents and rural women. In 2008, Armenia nearly doubled financing for prenatal services and launched an initiative guaranteeing women free birth related services (). Armenia also provided enhanced monetary incentives to service providers, which reduced informal payment by women (UNICEF 2008). In 1988, France became the first country to license the use of medical abortions, wherein women are administered medication to induce abortion instead of undergoing surgery (Kimball 2020). Additionally, in 2013, the French health care system began covering the full cost of abortion - previously only 70 to 80 percent was covered - noting that it deemed this step to be critical to ensure all women access to abortion services (Kimball 2020).

In 1966, Estonia established a compulsory, national curriculum on human studies, which includes sexuality education. This educational program is provided in conjunction with youth counselling centres, which provide young people with free counselling on sexual and reproductive health, including safe sex, family planning, and STI prevention (Haldre et al., 2012). The national curriculum and the youth counselling centres are credited with the 
reduction of HIV and STI rates and increased condom and contraception use among adolescents (Haldre et al., 2012).

In Iceland, the Ministry of Education established the sexuality education framework, which serves as a regulation which schools must follows in the provision of sexuality education (Allen 2018). Sexuality education is mandatory, and as such, parents may not opt-out on behalf of their children. In 2011, Iceland earmarked funding specifically for the incorporation of education on sexual assault in school curricula (Leggon et al., 2015). In 2004, the United Kingdom's Department of Health issued best practice guidance to advise health care professionals about addressing the sexual and reproductive health needs of patients under the age of sixteen (16), such an accessing contraception (Travers et al., 2019).

\section{Examples of Countries in Africa:}

In 2002, the Constitutional Court of South Africa ruled that the government must remove restrictions on Nevirapine, a pharmaceutical which reduces the risk of mother-to-child transmission of HIV. The court ordered the state to take positive measures to permit facilities and expedite Nevirapine's use (Khoza 2002). Also, with the passage of the Choice on Termination of pregnancy Act, abortion became legal with restriction as to reason during the first 12 weeks of pregnancy (Khoza 2002; Ude \& Oben 2015). In 2012, the Namibian High Court decided the case of L.M and others $v$. The Government of the Republic of Namibia, where it ruled that medical practitioners in state-run hospitals involuntarily sterilized three women living with HIV (Khumalo 2019). Also in 2009, Kenya's Ministry of Health issued the National guidelines for the Medical Management of Rape/ Sexual Violence, which explicitly recognises the ICPD programme of Action.
In 2010, the United States of America passed the Patient Protection and Affordable Care Act, which greatly expanded women's access to preventive health care, including contraceptives, without cost-sharing requirements such as co-payments or deductibles (Shaw et al., 2014). In accordance with the law, most employers are required to include contraception for their employees under their insurance schemes. This provision ensures that women who are insured and able to afford contraceptives and therefore, are better equipped to plan the number and spacing of their children.

\section{National}

Nigeriain trying toeffectuate commitments made at the ICPD and Beijing Conferenceshas encountered series of deprecatory challenges in her determined attempt. Little progress has been made so far as Nigeria has ratified and signed various regional, international treaties and instruments that affirm the right to health with implications for reproductive health care of women (Aniekwu 2006). But some of these documents that have been ratified has not been domesticated into our municipal laws and become inapplicable bring about a setback in the development of reproductive health laws. These documents includes; the International Covenant on Civil and Political Rights (ICCPR) of 1966, (Joseph \& Castan 2013), the International Covenant on Economic, Social and Cultural Rights (ICESCR) (Ssenyonjo 2017), the International Covenant on the Elimination of AllForms of Racial Discrimination (ICERD), the Convention on the Elimination of All Forms of Discrimination against Women (CEDAW) and the Convention on the Rights of the Child. It is pertinent to note that Nigeria has domesticated the African Charter on Human and Peoples Rights (ACHPR) by virtue of the African Charter on Human and Peoples" Rights (Ratification 
and Enforcement) Act (Ssenyonjo 2017). Also, by virtue of section 54 of the Labour Act, maternal health is recognized by providing for maternal leave before and after confinement. The National Health policy which became operative in October, 1988 by the Nigerian Government aims at a level of health that will enable Nigerians achieve socially and economically productive lives. It adopts the primary health concept as the main engine by which the goal of health for all Nigerians can be attained (Onoka et al., 2015).

The National Reproductive and Health Policy and Strategy provide for a redirection in programming and service delivery methods (Onoka et al., 2015). It also aims 'to provide the necessary guidance and framework for the promotion and implementation of reproductive health programmes and activities. Other National Health Policies and programs on Reproductive health issues in Nigeria are (Onoka et al., 2015);

1) National HIV/AIDS and Reproductive Health Survey (2005)

2) National HIV/AIDS Workplace Policy (2005)

3) National Population Policy for Sustainable Development 1988 (revised in 2003)

4) National Policy on HIV/AIDS (2003)

5) National Reproductive Health Strategic Plan (2002)

6) National Policy on the Elimination of Female Genital Mutilation (1998, 2002)

7) Maternal and Child Health Policy (1994)

8) National Adolescent Health Policy (1995)

9) HIV Emergency Action Plan

10) National Policy on VVF

11) National Economic Empowerment and Development Strategy (NEEDS)

12) The State Economic Empowerment Development Scheme (SEEDS)
13) The National Policy on Population for Development, Unity, Progress and Self Reliance, etc.

On the 25th May, 2015 the Violence Against Persons Prohibition Act (VAPP) was signed by into law by the former President Goodluck Jonathan after it has been earlier passed by the National Assembly on the $4^{\text {th }}$ of May 2015 (Nwazuoke 2016). The VAPP Act can be considered as a step in the right direction with Nigeria's international obligations under CEDAW and the Protocol to the African Charter on Human and Peoples' Rights on the Rights of Women in Africa (Mujuzi 2008). The VAPP Act 2015 has been regarded as the first national reproductive health legislation to "prohibit and punish female genital mutilation,forced eviction by a person of his/her spouse and children, verbal, emotional and psychological abuses, harmful widowhood practices, political violence, etc" (Anyogu \& Okpalaobi 2017, p. 37). Moreover, many States in the country (Nigeria) have enacted specific laws on women's health and gender issues as they relate to reproductive health care (Anyogu \& Okpalaobi 2017). Nigeria states have strived in the development of reproductive health laws but still faces some challenges with involves customary practices and these cultural practice varies from locality to locality.

For example, there has been no law enacted to enhance safe abortions in Nigeria (). Also, many marriages of very young girls still persists as cultural laws despite the minimum marriageable age of eighteen (18) years prescribed by the National Policy on Population and other Marriage Acts (Rasch 2011). While many countries have enacted laws aiming to ensure access to sexual reproductive health services and laws punishing gender-based violence and other harmful traditional practices, lack of implementation frequently results in frameworks which do not effectively fulfil individuals' sexual and 
reproductive health and rights (Ubajaka et al., 2014). By incorporating accountability mechanisms during the crafting and implementation of laws and policies, states can better ensure that laws and policies will be effectively implemented.

\section{RECOMMENDATIONS}

The following recommendations suggested in the development of Reproductive Health laws;

1) States should guarantee the rights to autonomy and to be free from discrimination by taking measures in implementing laws and policies prohibiting discrimination in the provision of reproductive health services as well as developing laws that address the sexual and reproductive health care taking into consideration the specific needs of marginalized population.

2) States should eliminate coercion in reproductive care by establishing mechanisms to identify coercive practices, to hold health care providers accountable for such violations, and ensure victims of coercion access to remedies and compensation.

3) States should ensure that sexual and reproductive health information and services are available, accessible, acceptable, and of good quality by guaranteeing comprehensive reproductive health care is affordable, geographically accessible and administered without discrimination, stigma, or maltreatment.

4) States should enhance accountability and ensure laws are fully implemented by utilizing inclusive and broad-based participatory processes involving key stakeholders in the formulation, implementation and monitoring of laws, including relevant government bodies, ministries, and external stakeholders such as civil society.
5) States should ensure that laws and policies being implemented are attaining their desired aims by collecting disaggregated data on access to and use of sexual and reproductive health services.

6) To comply with their national legal obligation, states should ensure that individuals harmed by human rights violations have access to appropriate and adequate remedies.

7) States should conduct thorough, fair, and impartial investigations into allegations of sexual and reproductive rights violations.

\section{CONCLUSION}

The International Conference on Population and Development (ICPD) remains the most significant instrument for the modern development of law in reproductive health care. The ICPD Programme of action is not an international law, but a mere policy declaration. As a result of its long use and recognition in the international community, it is seen to qualify as an international customary law, thus; it is a source of international law. The ICPD is an exceptional instrument containing population policies geared towardempowering couples and individuals specifically women to create decisions about the size of their families, providing them with the knowledge and resources to form such decisions, and facilitating them to exercise their reproductive rights (Wekwete 2014). This document has now been accepted in domestic and international law.

Although, many of these policies provided within the ICPD lacks binding force and enforceability, but much responsibility now lies in the hands of the competent political bodies to make certain that various countries come up with proper measures of enhancing state parties' implementation. 


\section{REFERENCES}

Allen, L. (2018). Sexuality education and new materialism: Queer things. Springer.

Aniekwu, N. I. (2011). Reproductive Health Law: A Jurisprudential Analysis of Gender Specific Human Rights for the African Region. Department of Public Law, Faculty of Law, University of Benin.

Anyogu, F., \& Okpalaobi, B. N. (2017). Violence against Persons (Prohibition) Act 2015 and other existing gender legislation: a comparative analysis. Nnamdi Azikiwe University Journal of International Law and Jurisprudence, 8(1), 35-39.

D'Amato, A. A., \& Abbassi, J. (2006). International law today: A handbook. West Academic.

Defeis, E. F. (2010). The United Nations and Women-A Critique. Wm. \& Mary J. Women \& L., 17, 395.

Englehart, N. A., \& Miller, M. K. (2014). The CEDAW effect: international law's impact on women's rights. Journal of Human Rights, 13(1), 22-47.

Federal Republic of Nigeria. (1999). Constitution of the Federal Republic of Nigeria.

Gable, L. (2009). Reproductive health as a human right. Case W. Res. L. Rev., 60, 957.

Ghabbour, S. I. (1994). United Nations International Conference on Population and Development (ICPD), held in the International Conference Centre, Cairo, Egypt, during 5-13 September 1994. Environmental

Conservation, 21(3), 283-284.

Glahn, G., \& Taulbee, J. L. (2015). Law among nations: an introduction to public international law. Routledge.

Haldre, K., Part, K., \& Ketting, E. (2012). Youth sexual health improvement in Estonia, 1990-2009: the role of sexuality education and youthfriendly services. The European Journal of Contraception \& Reproductive Health Care,17(5), 351-362.

Heyns, C. H., \& Viljoen, F. (Eds.). (2002). The impact of the United Nations human rights treaties on the domestic level. Martinus Nijhoff Publishers.

Ibekwe, F. A., Aloamaka, P. C., \& Besong, P. (2020). An Inter-Jurisdictional Approach To International Protection of Minority Rights. UNIPORT Journal of International and Comparative Law, 187

Ikonomwan, O., Aloamaka, P. C. (2018). Issues Beleaguering The Nigerian Aviation Sector: Proposing Legal Reforms. Journal Benin Bar Journal, 1(1), 149-169

Ikonomwan, O., Aloamaka, P. C. (2020). Protection of Reproductive Health Care In Nigeria: The Role of The International Conference On Population And Development (ICPD). Journal Benin Bar Law Journal, 2(1),17-31.

Joseph, S., \& Castan, M. (2013). The international covenant on civil and political rights: cases, materials, and commentary. Oxford University Press.

Khoza, S. (2002). Reducing mother-to-child transmission of HIV: the Nevirapine case article. ESR Review: Economic and Social Rights in South Africa, 3(2), 2-6.

Khumalo, L. R. (2019). Has the LM and Others $v$ Government of the Republic of Namibia case closed the door on the claim of unfair discrimination by HIV positive women alleging to have been coerced or forced into being sterilised because of their HIV status?: A critical analysis of a possibility of a class action or a public interest action on behalf of 
South African women living with HIV who have been sterilised without their informed consent (Doctoral dissertation).

Kimball, N. L. (2020). 5. Unwanted Pregnancy and Abortion in the Wake of Democracy, 1982-2010. In An Open Secret (pp. 183-218). Rutgers University Press.

Leggon, C., McNeely, C. L., \& Yoon, J. (2015). Advancing women in science: Policies for progress. In Advancing Women in Science (pp. 307-340). Springer, Cham.

Mujuzi, J. D. (2008). The Protocol to the African Charter on Human and Peoples' Rights on the Rights of Women in Africa: South Africa's reservations and interpretative declarations. Law, Democracy \& Development, 12(2), 41-61.

Nielsen, R. A., \& Simmons, B. A. (2015). Rewards for Ratification: Payoffs for Participating in the International Human Rights Regime?. International Studies Quarterly, 59(2), 197-208.

Nwazuoke, A. N. (2016). A Critical Appraisal of the Violence against Persons (Prohibition) Act, 2015.JL Pol'y \& Globalization, 47, 69.

Onoka, C. A., Hanson, K., \& Hanefeld, J. (2015). Towards universal coverage: a policy analysis of the development of the National Health Insurance Scheme in Nigeria.Health policy and planning, 30(9), 1105-1117.

Patel, V., Chisholm, D., Parikh, R., Charlson, F. J., Degenhardt, L., Dua, T., ... \& Whiteford, H. (2016). Addressing the burden of mental, neurological, and substance use disorders: key messages from Disease Control Priorities. The Lancet, 387(10028), 1672-1685.
Rahman, M. (Ed.). (2003). Gender Equality in Bangladesh: Still a Long Way to Go. NewsNetwork.

Rasch, V. (2011). Unsafe abortion and postabortion care-an overview. Acta obstetricia et gynecologica Scandinavica, 90(7), 692-700.

Shapiro, G. K. (2014). Abortion law in Muslim-majority countries: an overview of the Islamic discourse with policy implications. Health policy and planning, 29(4), 483-494.

Shaw, F. E., Asomugha, C. N., Conway, P. H., \& Rein, A. S. (2014). The Patient Protection and Affordable Care Act: opportunities for prevention and public health. The Lancet, 384(9937), 75-82.

Ssenyonjo, M. (2017). The Influence of the International Covenant on Economic, Social and Cultural Rights in Africa. Netherlands International Law Review, 64(2), 259-289.

Travers, M., O'Uhuru, D., Mueller, T., \& Bedell, J. (2019). Implementing adolescent sexual and reproductive health clinical best practice in the Bronx, New York.Journal of Adolescent Health, 64(3), 376-381.

Ubajaka, C. F., Adogu, P. O., Ilika, C., \& Ilika, A. L. (2014). Perception of abortion and abortion laws by lawyers in Anambra State Nigeria. International Journal of Clinical Medicine, 2014.

Ude, B., \& Oben, B. (2015). Public policy as an instrument for conflict prevention: A case study of Niger Delta conflict and Bakassi imbroglio. Calabar Journal of Politics and Administration, 4(1), 235-243.

Udungeri, K. U., Aloamaka, P. C. (2017). Polluters Pays Principle Under The Nigeria Oil And Gas Law. Journal Calabar Law Journal, 18, 99-114 
UNICEF. (2008). The state of the world's children 2009: maternal and newborn health (Vol. 9). Unicef.

Wekwete, N. N. (2014). Gender and economic empowerment in Africa:
Evidence and policy.Journal of African Economies,23(suppl_1), i87-i127. 